\title{
DIOLMYCINS, NEW ANTICOCCIDIAL AGENTS PRODUCED BY Streptomyces sp. \\ I. PRODUCTION, ISOLATION AND PHYSICO-CHEMICAL AND BIOLOGICAL PROPERTIES
}

\author{
Noriko Tabata, Hiroshi Tomoda, Yōko Takahashi, Katsuji Haneda, \\ YUZuru IWAI, H. Boyd WOODRUfF and SATOSHI OMUra* \\ Research Center for Biological Function, The Kitasato Institute, \\ Minato-ku, Tokyo 108, Japan
}

(Received for publication December 21, 1992)

\begin{abstract}
Streptomyces sp. WK-2955, a soil isolate, was found to produce a series of new anticoccidial compounds. Four active compounds, designated diolmycins A1, A2, B1 and B2, were isolated from the fermentation broth of the producing strain by solvent extraction, silica gel column chromatography, gel filtration on Sephadex LH-20, and preparative HPLC. Diolmycins inhibited the growth of Eimeria tenella in an in vitro assay system using BHK-21 cells as a host. No schizont in the cells was observed at concentrations of $0.02 \sim 2.0 \mu \mathrm{g} / \mathrm{ml}$ for diolmycin Al, at $0.2 \sim 2.0 \mu \mathrm{g} / \mathrm{ml}$ for diolmycin A2, and at $20 \mu \mathrm{g} / \mathrm{ml}$ for diolmycins B1 and B2.
\end{abstract}

Recently, we have reported new anticoccidial agents named xanthoquinodins ${ }^{1}$. From our continuous screening system using BHK-21 cells as a host and monensin-resistant Eimeria tenella as a parasitic protozoa, an actinomycetes strain WK-2955 was found to produce a series of new anticoccidial agents. Eventually, four active compounds, termed diolmycins A1, A2, B1 and B2 (Fig. 1), were isolated. In this paper, the taxonomy of the producing strain, fermentation, isolation and physico-chemical and biological properties of diolmycins are described. The structure and synthesis of diolmycin will be presented in the accompanying paper ${ }^{2}$.

Taxonomy of the Producing Strain WK-2955

To investigate the cultural and physiological characteristics, the International Streptomyces Project (ISP) media, recommended by SHIRLING and GOTTLIEB ${ }^{3)}$ and by WAKSMAN ${ }^{4)}$, were used. Cultures were observed after incubation at $27^{\circ} \mathrm{C}$ for 2 weeks. The utilization of carbon sources was tested by growth on

Fig. 1. Structures of diolmycins A1, A2, B1 and B2.<smiles>Oc1ccc(CC(O)C(O)Cc2c[nH]c3ccccc23)cc1</smiles>

Diolmycin Al<smiles>Oc1ccc(CC(O)C(O)Cc2ccc(O)cc2)cc1</smiles>

Diolmycin B1<smiles>Oc1ccc(CC(O)[C@@H](O)Cc2c[nH]c3ccccc23)cc1</smiles>

Diolmycin A2<smiles>Oc1ccc(CC(O)C(O)Cc2ccc(O)cc2)cc1</smiles>

Diolmycin B2 
PrIDHAM's medium ${ }^{5,6)}$ containing $1 \%$ carbon source at $27^{\circ} \mathrm{C}$. The vegetative mycelia grew abundantly on both synthetic and complex agar media, and did not show fragmentation into coccoid or bacillary elements. The aerial mycelia grew abundantly on yeast extract - malt extract agar and inorganic salts - starch agar. The mature sporophores were of the Rectiflexibilis type and had more than 20 spores per chain (Fig. 2). The spores were cylindrical in shape, $1.0 \times 0.6 \mu \mathrm{m}$ in size, and had a smooth surface. Sclerotic granules, sporangia, and flagellated spores were not observed. The cultural characteristics, physiological properties, and utilization of carbon sources are shown in Tables 1, 2 and 3, respectively. The color of vegetative mycelia was pink or wine and that of aerial mycelia was pink or white. Melanin and other pigments were not produced. The type of diaminopimelic acid (DAP) was determined by the method of TAKAHASH et al $^{7)}$. The DAP isomer in cell wall of strain WK-2955 was determined to be

Fig. 2. Scanning electron micrograph of spore chains of strain WK-2955 grown on tyrosin agar for 14 days.

Bar represents $1.0 \mu \mathrm{m}$.

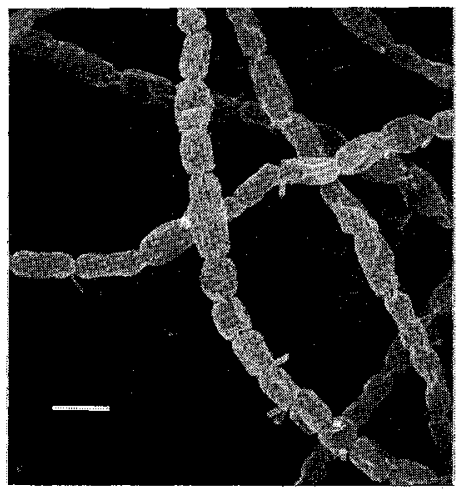

Table 1. Cultural characteristics of strain WK-2955.

\begin{tabular}{|c|c|c|c|c|c|}
\hline Medium & & Cultural characteristics & Medium & & Cultural characteristics \\
\hline $\begin{array}{l}\text { Yeast extract - malt } \\
\text { extract agar }\end{array}$ & $\begin{array}{r}\text { G: } \\
\mathrm{R}: \\
\text { AM: } \\
\text { SP: }\end{array}$ & $\begin{array}{l}\text { Good, mapple (4le) } \\
\text { Luggage tan (4ne) } \\
\text { Abundant, fresh pink (6ca) } \\
\text { None }\end{array}$ & Tyrosine agar $^{\mathrm{a}}$ & $\begin{array}{r}\mathrm{G}: \\
\mathrm{R}: \\
\mathrm{AM}:\end{array}$ & $\begin{array}{l}\text { Moderate, cedar }(6.5 \mathrm{le}) \\
\text { Ash rose }(7 \mathrm{ie}) \\
\text { Moderate, light orchid } \\
\text { pink }(9 \mathrm{ca})\end{array}$ \\
\hline Oatmeal agar ${ }^{\mathbf{a}}$ & $\begin{array}{r}\text { G: } \\
\text { R: } \\
\text { AM: } \\
\text { SP: }\end{array}$ & $\begin{array}{l}\text { Good, pearl pink (3ca) } \\
\text { Pearl pink (3ca) } \\
\text { Poor, shell pink ( } 5 \mathrm{ba}) \\
\text { None }\end{array}$ & $\begin{array}{l}\text { Sucrose-nitrate } \\
\text { agar }^{b}\end{array}$ & $\begin{array}{r}\text { SP: } \\
\text { G: } \\
\text { R: } \\
\text { AM: }\end{array}$ & $\begin{array}{l}\text { None } \\
\text { Good, light ivory (2ca) } \\
\text { Light wheat ( } 2 \mathrm{ca}) \\
\text { Moderate, shell pink ( } 5 \mathrm{ba})\end{array}$ \\
\hline $\begin{array}{c}\text { Inorganic salts - } \\
\text { starch agar }\end{array}$ & $\begin{array}{r}\text { G: } \\
\mathrm{R}: \\
\text { AM: } \\
\text { SP: }\end{array}$ & $\begin{array}{l}\text { Good, pearl pink ( } 3 \mathrm{ca}) \\
\text { Salmon pink (5ga) } \\
\text { Abundant, shell pink (5ba) } \\
\text { None }\end{array}$ & $\begin{array}{l}\text { Glucose - nitrate } \\
\text { agar }^{\mathrm{b}}\end{array}$ & $\begin{array}{r}\text { SP: } \\
\mathrm{G}: \\
\mathrm{R}: \\
\text { AM: }\end{array}$ & $\begin{array}{l}\text { None } \\
\text { Moderate, fresh pink ( } 4 \mathrm{ca}) \\
\text { Light apricot ( } 4 \mathrm{ea}) \\
\text { Moderate, shell pink ( } 5 \mathrm{ba})\end{array}$ \\
\hline $\begin{array}{l}\text { Glycerol - asparagine } \\
\text { agar }^{2}\end{array}$ & $\begin{array}{r}\text { G: } \\
\text { R: } \\
\text { AM: } \\
\text { SP: }\end{array}$ & $\begin{array}{l}\text { Good, pearch }(5 \mathrm{ga}) \\
\text { Copper }(5 \mathrm{lc}) \\
\text { Moderate, white (a) } \\
\text { None }\end{array}$ & $\begin{array}{l}\text { Giycerol-calcium } \\
\text { malate agar }\end{array}$ & $\begin{array}{r}\text { SP: } \\
\mathrm{G}: \\
\mathrm{R}: \\
\mathrm{AM}:\end{array}$ & $\begin{array}{l}\text { None } \\
\text { Good, rose wine }(8 \mathrm{le}) \\
\text { Rose wine }(8 \mathrm{le}) \\
\text { Moderate, pale pink }(8 \mathrm{ca})\end{array}$ \\
\hline $\begin{array}{l}\text { Glucose - asparagine } \\
\text { agar }\end{array}$ & $\begin{array}{r}\mathrm{G}: \\
\mathrm{R}: \\
\mathrm{AM}: \\
\mathrm{SP}:\end{array}$ & $\begin{array}{l}\text { Good, apricot (4ia) } \\
\text { Fresh pink (4ca) } \\
\text { Moderate, melon yellow } \\
\quad \text { (3ia) } \\
\text { None }\end{array}$ & $\begin{array}{l}\text { Glucose-peptone } \\
\text { agar }^{\text {b }}\end{array}$ & $\begin{array}{r}\text { SP: } \\
\text { G: } \\
\text { R: } \\
\text { AM: } \\
\text { SP: }\end{array}$ & $\begin{array}{l}\text { None } \\
\text { Good, pearl pink (3ca) } \\
\text { Pearl pink (3ca) } \\
\text { Moderate, shell pink ( } 5 \mathrm{ba}) \\
\text { None }\end{array}$ \\
\hline $\begin{array}{l}\text { Peptone - yeast } \\
\text { extract - iron agar }{ }^{\mathrm{a}}\end{array}$ & $\begin{array}{r}\text { G: } \\
\text { R: } \\
\text { AM: } \\
\text { SP: }\end{array}$ & $\begin{array}{l}\text { Moderate, light ivory }(2 \mathrm{ca}) \\
\text { Light wheat }(2 \mathrm{ea}) \\
\text { None } \\
\text { None }\end{array}$ & Nutrient agar ${ }^{b}$ & $\begin{array}{r}\text { G: } \\
\text { R: } \\
\text { AM: } \\
\text { SP: }\end{array}$ & $\begin{array}{l}\text { Moderate, pearl pink (3ca) } \\
\text { Pearl pink (3ca) } \\
\text { Moderate, white (a) } \\
\text { None }\end{array}$ \\
\hline
\end{tabular}

a Medium recommended by International Streptomyces Project.

b Medium recommended by S.A. Waksman.

Abbreviation: G, Growth of vegetative mycelium; R, reverse; AM, aerial mycelium; SP, soluble pigment.

( ): Color number designations taken from Color Harmony Manual, 4th Ed., Container Corporation of America, Chicago, Illinois, U.S.A., 1958. 
Table 2. Physiological properties of strain WK-2955.

\begin{tabular}{lc}
\hline Melanin formation & - \\
Tyrosinase reaction & - \\
$\mathrm{H}_{2}$ S production & - \\
Nitrate reduction & - \\
Liquefaction of gelatin $\left(21 \sim 23^{\circ} \mathrm{C}\right)$ & - \\
Peptonization of milk $\left(36 \sim 37^{\circ} \mathrm{C}\right)$ & - \\
Coagulation of milk $\left(36 \sim 37^{\circ} \mathrm{C}\right)$ & - \\
Cellulolytic activity & - \\
Hydrolysis of starch & + \\
Temperature range for growth & $15 \sim 37^{\circ} \mathrm{C}$ \\
\hline,+ Active; - , not active.
\end{tabular}

Table 3. Utilization of carbon sources by strain WK-2955.

\begin{tabular}{lc}
\hline D-Glucose & + \\
D-Fructose & + \\
L-Rhamnose & + \\
D-Mannitol & + \\
L-Arabinose & + \\
i-Inositiol & + \\
Raffinose & + \\
D-Xylose & + \\
Sucrose & - \\
Melibiose & + \\
Cellulose & - \\
\hline
\end{tabular}

+ , Utilized; - , not utilized.
Fig. 3. Time course of diolmycins A1 and A2 production in a 30 -liter jar fermentor.

- Diolmycin A1, $\Delta$ diolmycin A2, O packed cell volume, $\mathbf{a} \mathrm{pH}$.
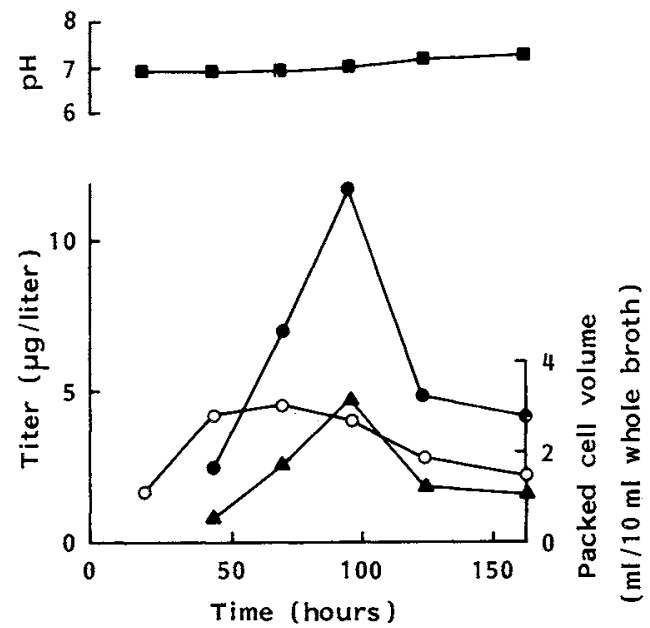

of the LL-type. Based on the taxonomic properties described above, it is reasonable to conclude that strain WK-2955 belongs to the genus Streptomyces ${ }^{8)}$. The strain was deposited in the Fermenta-

tion Research Institute, Agency of Industrial Science and Technology, Japan, under the name Streptomyces sp. WK-2955 and the accession number is FERM P-12318.

\section{Fermentation}

A slant culture of strain WK-2955 grown on Seino agar (starch $1.0 \%, \mathrm{~N}-\mathrm{Z}$ amine $0.3 \%$, yeast extract $0.1 \%$, meat extract $0.1 \%, \mathrm{CaCO}_{3} 0.3 \%$, agar $1.0 \%, \mathrm{pH} 7.0$ ) was used to inoculate $500-\mathrm{ml}$ Erlenmeyer flasks containing $100 \mathrm{ml}$ of a seed medium (glucose $0.1 \%$, starch $2.4 \%$, peptone $0.3 \%$, meat extract $0.3 \%$, yeast extract $0.5 \%, \mathrm{CaCO}_{3} 0.4 \%, \mathrm{pH} 7.0$ ). The flasks were shaken on a rotary shaker for 3 days at $27^{\circ} \mathrm{C}$. Two hundred $\mathrm{ml}$ of the seed culture was transferred into 20 liters of a production medium (glycerol $2.0 \%$, soy bean meal $2.0 \%, \mathrm{NaCl} 0.3 \%, \mathrm{pH} 7.0$ ) in a 30 -liter jar fermentor. The fermentation was carried out at $27^{\circ} \mathrm{C}$. A typical time course of the fermentation is shown in Fig. 3. The production of diolmycins A1 and A2 was measured by HPLC under the following conditions: column; YMC packed column R-ODS-5 $(4.6 \times 200 \mathrm{~mm})$, solvent; $40 \%$ aq $\mathrm{MeOH}$, detection; UV at $280 \mathrm{~nm}$, flow rate; $0.8 \mathrm{ml} /$ minute. Under these conditions, diolmycin A1 was eluted first with a retention time at 39.0 minutes, followed by diolmycin A2 at 43.7 minutes (Fig. 4a). The concentration of diolmycins A1 and A2 reached a maximum at 96 hours.

\section{Isolation}

Four-day cultured broth (20 liters) was extracted with 20 liters of ethyl acetate. The extracts were concentrated in vacuo to dryness to yield a red oily material $(56.9 \mathrm{~g})$. The material was distributed by $n$-hexane - $\mathrm{MeOH}-\mathrm{H}_{2} \mathrm{O}(40: 19: 1)$. Then the lower layer was concentrated in vacuo to dryness to yield a red material $(6.44 \mathrm{~g})$. The material was applied on a silica gel column (E. Merck, Kiselgel $60,500 \mathrm{ml}$ ). 
Fig. 4.

(a)

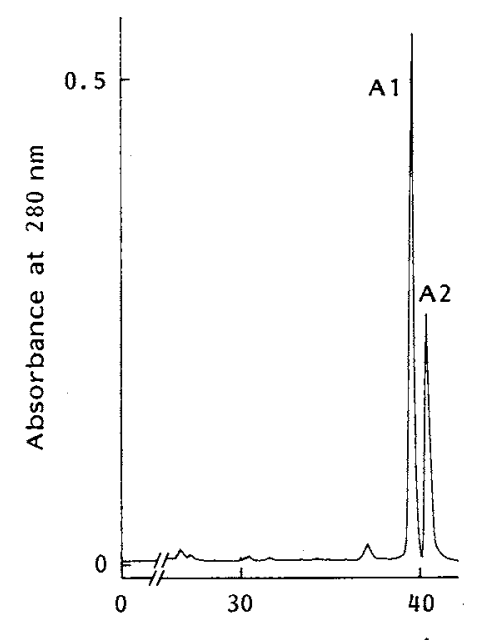

(b)

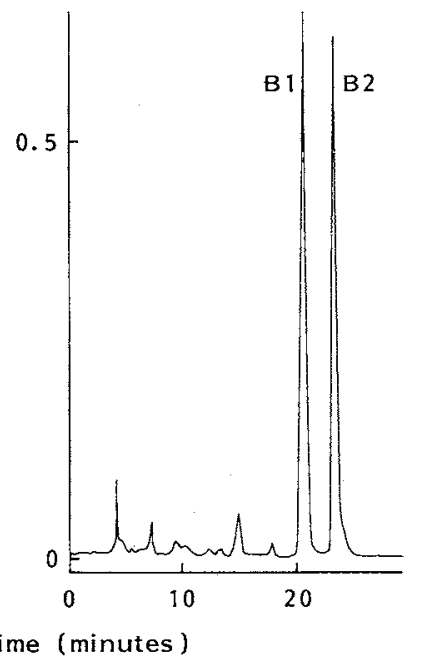

(a) A chromatographic profile of diolmycins A1 and A2 separated by analytical HPLC. Column: YMC-Packed column R-ODS-5 $(4.6 \times 200 \mathrm{~mm})$; mobile phase: $40 \%$ aq MeOH; flow rate: $0.8 \mathrm{ml} / \mathrm{minute}$; detection: $280 \mathrm{~nm}$.

(b) A chromatographic profile of diolmycins B1 and B2 separated by analytical HPLC. Column: YMC-Packed column R-ODS-5 $(4.6 \times 200 \mathrm{~mm})$; mobile phase: $35 \%$ aq $\mathrm{CH}_{3} \mathrm{CN}$; flow rate: $0.7 \mathrm{ml} / \mathrm{minute}$; detection: $280 \mathrm{~nm}$.

The column was washed with 1.5 liters of chloroform and 2.0 liters of chloroform-methanol $(50: 1)$. The active components were eluted with 2.0 liters of chloroform-methanol $(20: 1)$, and each $60 \mathrm{ml}$ was successively collected. The 9 th to 31 st fractions enriched with diolmycins A1, A2, B1 and B2 were concentrated in vacuo to give a red material $(270 \mathrm{mg})$. Further purification of diolmycins was carried out on gel filtration by Sephadex LH-20 $(2 \times 120 \mathrm{~cm}, \mathrm{MeOH}, 0.6 \mathrm{ml} /$ minute $)$. The active components were eluted with $500 \mathrm{ml}$ of methanol, and each $8.5 \mathrm{ml}$ was successively collected. The 33rd to 37 th fractions enriched with diolmycins $\mathrm{A} 1$ and $\mathrm{A} 2$ and the 30th to 32nd fractions with diolmycins B1 and B2 were evaporated in vacuo to give colorless materials (18.0 and $6.5 \mathrm{mg}$, respectively). Diolmycins A1 and A2 were finally purified by preparative HPLC (column; YMC pack D-ODS-5, $20 \times 250 \mathrm{~mm}, 40 \%$ aq $\mathrm{MeOH}$, UV at $280 \mathrm{~nm}, 6.0 \mathrm{ml} / \mathrm{minute}$ ). The active fractions were concentrated and extracted with ethyl acetate to give pure diolmycins A1 $(9.76 \mathrm{mg})$ and $\mathrm{A} 2(5.33 \mathrm{mg})$ as colorless materials. Diolmycins B1 and B2 were also purified by HPLC (column; YMC packed column R-ODS-5, $4.6 \times 200 \mathrm{~mm}, 35 \%$ aq $\mathrm{CH}_{3} \mathrm{CN}$, UV at $280 \mathrm{~nm}, 0.7 \mathrm{~m} 1 /$ minute) (Fig. $4 \mathrm{~b}$ ). The active fractions were also concentrated and extracted with ethyl acetate to give pure diolmycins B1 $(1.83 \mathrm{mg})$ and B2 $(0.54 \mathrm{mg})$ as colorless materials.

\section{Physico-chemical Properties}

The physico-chemical properties of diolmycins A1, A2, B1 and $\mathbf{B} 2$ are summarized in Table 4. The molecular formula of diolmycins $A 1$ and $A 2$ were determined both to be $\mathrm{C}_{18} \mathrm{H}_{19} \mathrm{NO}_{3}$ on the basis of HREI-MS. Similar UV spectra of diolmycins A1 and A2 were observed with three maxima at 222, 280 and $290 \mathrm{~nm}$ in $\mathrm{MeOH}$ (Fig. 5). The molecular formula of diolmycins $\mathrm{B} 1$ and $\mathrm{B} 2$ were also determined both to be $\mathrm{C}_{16} \mathrm{H}_{18} \mathrm{O}_{4}$. UV spectra of diolmycins $\mathrm{B} 1$ and $\mathrm{B} 2$ showed three maxima at 223, 277 and $285 \mathrm{~nm}$ in $\mathrm{MeOH}$ (Fig. 5). These data indicate that diolmycins A1, A2, B1 and B2 are new compounds. Their 
Table 4. Physico-chemical properties of diolmycins A1, A2, B1 and B2.

\begin{tabular}{|c|c|c|c|c|}
\hline & Diolmycin Al & Diolmycin A2 & Diolmycin B1 & Diolmycin $\mathrm{B} 2$ \\
\hline Appearance & Colorless powder & Colorless powder & Colorless powder & Colorless powder \\
\hline$[\alpha]_{\mathrm{D}}^{25}(c 0.1, \mathrm{MeOH})$ & $-8.0^{\circ}$ & $-12.0^{\circ}$ & $-6.0^{\circ}$ & $-6.7^{\circ}$ \\
\hline Molecular formula & $\mathrm{C}_{18} \mathrm{H}_{19} \mathrm{NO}_{3}$ & $\mathrm{C}_{18} \mathrm{H}_{19} \mathrm{NO}_{3}$ & $\mathrm{C}_{16} \mathrm{H}_{18} \mathrm{O}_{4}$ & $\mathrm{C}_{16} \mathrm{H}_{18} \mathrm{O}_{4}$ \\
\hline \multicolumn{5}{|l|}{ HREI-MS $(m / z)$} \\
\hline Calcd: & 297.1364 & 297.1364 & 274.1204 & 274.1204 \\
\hline Found: & 297.1363 & 297.1361 & 274.1207 & 274.1187 \\
\hline \multirow{3}{*}{$\mathrm{UV} \lambda_{\max }^{\mathrm{MeOH}}(\mathrm{nm})$} & $222(33,300)$ & $222(33,700)$ & $223(24,000)$ & $223(24,900)$ \\
\hline & $280(5,900)$ & $280(6,200)$ & $277(5,500)$ & $277(5,700)$ \\
\hline & $290(4,500)$ & $290(4,500)$ & $285(4,600)$ & $285(4,700)$ \\
\hline \multicolumn{5}{|l|}{ Solubility } \\
\hline Soluble: & $\mathrm{MeOH}, \mathrm{DMSO}$ & $\mathrm{MeOH}, \mathrm{DMSO}$ & $\mathrm{MeOH}, \mathrm{DMSO}$ & $\mathrm{MeOH}, \mathrm{DMSO}$ \\
\hline Insoluble: & $\mathrm{CHCl}_{3}$ & $\mathrm{CHCl}_{3}$ & $\mathrm{CHCl}_{3}$ & $\mathrm{CHCl}_{3}$ \\
\hline \multicolumn{5}{|l|}{ Color reaction } \\
\hline Positive & $50 \% \mathrm{H}_{2} \mathrm{SO}_{4}$ & $50 \% \mathrm{H}_{2} \mathrm{SO}_{4}$ & $50 \% \mathrm{H}_{2} \mathrm{SO}_{4}$ & $50 \% \mathrm{H}_{2} \mathrm{SO}_{4}$ \\
\hline Negative & Ninhydrin reagent & Ninhydrin reagent & Ninhydrin reagent & Ninhydrin reagent \\
\hline
\end{tabular}

Fig. 5. UV spectra of diolmycin Al (-) and B1 (---) (in $\mathrm{MeOH}$ ).

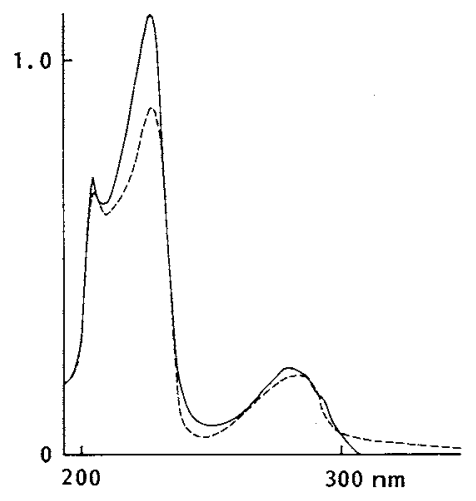

structures will be reported in the following paper $^{2)}$.

\section{Biological Properties}

Effect on Anticoccidial Activity in an In Vitro System

Anticoccidial activity in vitro was assayed as reported previously ${ }^{1)}$. Diolmycin A1 showed anticoccidial activity at concentrations ranging above $0.02 \mu \mathrm{g} / \mathrm{ml}$ (Table 5), indicating the highest anticoccidial potency among diolmycins. Diolmycins B1 and B2 showed poor anticoccidial activity at concentrations above $20 \mu \mathrm{g} / \mathrm{ml}$ (Table 5 ).

\section{Antimicrobial Activities}

Diolmycins A1, A2, B1 and B2 showed no antimicrobial activity in vitro at a concentration of $1 \mathrm{mg} / \mathrm{ml}$ against Staphylococcus aureus FDA 209P, Micrococcus luteus PCI 1001, Bacillus subtilis PCI 219, Mycobacterium smegmatis ATCC 607, Escherichia coli NIHJ, Escherichia coli NIHJ JC-2 IFO 12734,
Table 5. Anticoccidial activity of diolmycins A1, A2, $\mathrm{B} 1$ and $\mathrm{B} 2$ in an in vitro assay.

\begin{tabular}{lcc}
\hline & \multicolumn{2}{c}{$\begin{array}{c}\text { Minimum effective concentration } \\
(\mu \mathrm{g} / \mathrm{ml})\end{array}$} \\
\cline { 2 - 3 } Compounds & $\begin{array}{c}\text { Anticoccidial } \\
\text { activity }^{\mathbf{a}}\end{array}$ & Cytotoxicity $^{\mathbf{b}}$ \\
\hline Diolmycin A1 & 0.02 & 0.2 \\
Diolmycin A2 & 0.2 & 2.0 \\
Diolmycin B1 & 20 & $\mathrm{NT}^{\mathrm{d}}$ \\
Diolmycin B2 & 20 & $\mathrm{NT}^{\mathrm{d}}$ \\
Monensin & c c $^{\mathrm{c}}$ & 0.02 \\
\hline
\end{tabular}

BHK-21 cells stained with hematoxylin solution was microscopically observed. In control experiments (no drug) infected sporocysts grew in the cells to form mature shizonts.

a No mature shizonts observed in the cells when the drug was added to the culture medium at the indicated concentrations.

b No BHK-21 cells observed when the drug was added to the culture medium at the indicated concentrations.

c No anticoccidial activity.

d NT: Not tested higher than concentration of 20 $\mu \mathrm{g} / \mathrm{ml}$. 
Pseudomonas aeruginosa P-3, Xanthomonas oryzae, Bacteroides fragilis ATCC 23745, Acholeplasma laidlawii PG8, Candida albicans, Saccharomyces sake, Aspergillus niger ATCC 6275, Pyricularia oryzae, and Mucor racemosus IFO 4581.

\section{Discussion}

The diolmycin producer, Streptomyces sp. WK-2955 co-produced a great amount of red materials, presumably cytotoxic anthracyclines, which interfered with the isolation of diolmycins and the in vitro anticoccidial assay. Eventually, the final yields of diolmycins were quite low. Improvement of fermentation conditions to increase diolmycin production and to reduce red material production will be required.

The evaluation of diolmycin A1 in an in vivo system is being investigated.

\section{Acknowledgment}

We thank Ms. B. DENG for her assistance throughout this work.

\section{References}

1) Tabata, N.; Y. SuZumura, H. Tomoda, R. Masuma, K. Haneda, M. Kish, Y. Iwai \& S. Ōmura: Xanthoquinodins, new anticoccidial agents produced by Humicola sp. Production, isolation and physico-chemical and biological properties. J. Antibiotics 46: $749 \sim 755,1993$

2) Tabata, N.; T. Sunazuka, H. Tomoda, Y. Iwai \& S. Ōmura: Diolmycins, new anticoccidial agents produced by Streptomyces sp. II. Structure elucidation of diolmycins A1, A2, B1 and B2 and synthesis of diolmycin A1. J. Antibiotics 46: 762 769, 1993

3) Shirling, E. B. \& D. GotTlib: Methods for characterization of Streptomyces species. Int. J. Syst. Bacteriol. 16: $313 \sim 340,1966$

4) Waksman, S. A. (Ed.): The Actinomycetes. Vol. 2. Classification, Identification and Description of Genera and Species. pp. $327 \sim 334$, Williams \& Wilkins Co., Baltimore, 1961

5) Color Harmony Manual. 4th Ed. Container Corporation of America, Chicago, 1958

6) Pridham, T. G. \& D. Gotrlieb: The utilization of carbon compounds by some Actinomycetales as an aid for species determination. J. Bacteriol. 56: $107 \sim 114,1948$

7) Takahashi, Y.; Y. Iwai, H. Tomoda, N. Nimura, T. Kinoshita \& S. OMura: Optical resolution of 2,6-diaminopimelic acid stereoisomers by high performance liquid chromatography for the chemotaxonomy of actinomycete strains. J. Gen. Appl. Microbiol. 35: 27 32, 1989

8) Williams, S. T.; M. Goodfellow \& G. Alderson: Genus Streptomyces Waksman and Henrich 1943. In Bergey's Manual of Systematic Bacteriology. Volume 4. Ed., S. T. Williams et al., pp. $2452 \sim 2492$, Williams \& Wilkins Co., 1989 